\title{
Effect of forest fragmentation on microsporogenesis and pollen viability in Eugenia uniflora, a tree native to the Atlantic Forest
}

\author{
D.J. de Almeida ${ }^{1}$, M.V. Faria ${ }^{1,2}$ and P.R. da Silva ${ }^{1,3}$ \\ ${ }^{1}$ Programa de Pós-Graduação em Biologia Evolutiva, \\ Universidade Estadual do Centro-Oeste, Guarapuava, PR, Brasil \\ ${ }^{2}$ Departamento de Agronomia, Universidade Estadual do Centro-Oeste, \\ Guarapuava, PR, Brasil \\ ${ }^{3}$ Laboratório de Genética e Biologia Molecular Vegetal, \\ Departamento de Ciências Biológicas, \\ Universidade Estadual do Centro-Oeste, Guarapuava, PR, Brasil \\ Corresponding author: P.R. da Silva \\ E-mail: prsilva@unicentro.br
}

Genet. Mol. Res. 11 (4): 4245-4255 (2012)

Received March 2, 2012

Accepted June 11, 2012

Published September 20, 2012

DOI http://dx.doi.org/10.4238/2012.September.20.2

\begin{abstract}
Habitat fragmentation, caused by the expansion of agriculture in natural areas, may be one of the strongest impacts humans have on the ecosystem. These changes can decrease the number of individuals in a population, leading to endogamy. In allogamous species, endogamy can have a negative effect on reproductive capacity. In this study, we analyzed the effects of forest fragmentation on microsporogenesis and pollen viability in Eugenia uniflora L., a tree species native to the Atlantic Forest. We analyzed 4 populations, 3 of which were connected by forest corridors and 1 of which was isolated by agricultural fields on all sides. For microsporogenesis analysis, 9000 meiocytes representing all stages of meiosis were evaluated. To perform the pollen viability test, we evaluated 152,000 pollen grains. Microsporogenesis was stable in plants from populations that were
\end{abstract}


connected by forest corridors (abnormalities, less than 6\%), while microsporogenesis in plants from the isolated population showed a higher level of abnormalities (13-29\%). Average pollen viability was found to be more than $93 \%$ in the non-isolated populations and $82.62 \%$ in the isolated population. The $\chi^{2}$ test showed that, in the isolated population, the meiotic index was significantly lower than that in the non-isolated populations $(\mathrm{P}=0.03)$. The analysis of variance for the percentage of viable pollen grains confirmed the significant difference between the isolated and non-isolated populations. Our data show that forest fragmentation has a direct effect on microsporogenesis and pollen viability in E. uniflora and can directly influence the reproductive capacity of isolated populations of this species.

Key words: Isolated population; Genetic erosion; Endogamy; Meiosis; Myrtaceae

\section{INTRODUCTION}

A forest fragment is an area of natural vegetation interrupted by natural or anthropogenic barriers that can significantly reduce the flow of animals, pollen, or seeds. The advance of agriculture has been largely responsible for habitat fragmentation. Many authors have cited forest fragmentation as perhaps the most significant negative impact humans have on the environment because it reduces forest area, destroys habitat, and isolates populations (Green, 1994; Turner, 1996; Laurance et al., 2002; Armbrecht and Perfecto, 2003). The isolation caused by fragmentation has ecological and genetic implications, such as loss of habitat heterogeneity and loss of genetic variability (Bierregaard Jr. et al., 1992; Santos and Kinoshita, 2003; Rodríguez-Cabala et al., 2007; Bittencourt and Sebbenn, 2009). Fragmentation can affect the ability of populations to adapt to environmental changes and could compromise the future of the species (Barret et al., 1983; Noss, 1987; Kapos, 1989; Heldrick and Miller, 1992; Ellstrand and Elam, 1993). There is a growing interest in understanding the effects of fragmentation on the evolutionary history of natural populations of plants and animals and in investigating how to ensure the conservation and biodiversity of forest fragments (Becker et al., 1991; Bierregaard Jr. et al., 1992; Aizen and Feinsinger, 1994; Didham, 1998; Laurance et al., 2002; Wielgoss et al., 2010).

Eugenia uniflora Linneu 1735, popularly known as pitanga, Surinam cherry, and Brazilian cherry, is a member of the Myrtaceae family and a fruit-tree species native to the Atlantic Forest and widely distributed in Brazil (Piroli and Nascimento, 2008). According to Pelacani et al. (2000), the species is allogamous and dependent on pollinators. Estopa et al. (2007) stated that in populations of allogamous plants, deleterious genes are suppressed by heterozygosity. These same authors also stated that these genes, when homozygous, affect the reproductive viability of the plant. These characteristics make this species an interesting subject for studying the effects of fragmentation in natural populations. Although the effects of endogamy do not lead to depressed reproduction for all species (Ferreira et al., 2002; Estopa et al., 2007), information on these effects is necessary to assess how a species may be threatened when populations become isolated and also to define the best strategy for its conservation. 
Meiosis is an event of high evolutionary stability because it is directly related to the number of chromosomes in the gametes, and errors in the phases of meiosis directly lead to reproductive depression (Ricci et al., 2007). These errors can be conditioned by genetic or environmental factors (Pagliarini, 2002). When an allogamous plant is subjected to self-pollination, the population may become homozygous for many alleles, including those involved in the control of meiosis; this can cause irregularity in microsporogenesis, leading to reduced pollen viability (Ricci et al., 2007). The primary aim of this study was to analyze the effect of fragmentation on microsporogenesis and pollen viability in $E$. uniflora, a species native to the Atlantic Forest. We hypothesized that 1) autogamy increases in isolated populations of allogamous plants; 2) the autogamy can be expressed, resulting in changes in meiotic behavior, 3 ) and the abnormal meiotic behavior increases pollen sterility and reduces the reproductive capacity of the species.

\section{MATERIAL AND METHODS}

\section{Study areas}

Plant material was collected from 4 populations of E. uniflora that occupy 4 separate fragments in the Atlantic Forest located in Guarapuava County in the south-central region of Paraná, Brazil (Figure 1). Paraná is the largest grain producer in Brazil and most of its biomes have been completely fragmented by clearing for large areas of farmland. Guarapuava County is divided into 2 types of land. To the west of the urban area is the agricultural region that continues to the west of Paraná. The eastern region of the urban area is a large, conserved area comprising large forests that are connected by corridors of natural forests over hills and along rivers. These features make this region excellent for studying the effects of agricultural fragmentation on populations of native species. Among the fragments studied in this article, fragment $\mathrm{A}$ is located to the west of the Guarapuava urban area and is completely isolated (Figure 1). The other 3 fragments $(\mathrm{B}, \mathrm{C}$, and $\mathrm{D})$ are located to the east of the Guarapuava urban area and are connected by forest corridors either to each other or to other fragments not studied here (Figure 1). Plants from fragments A, B, C, and D have been referred to as "population A", "population B", "population C", and "population D", respectively. A summary of the characteristics of each fragment studied is shown in Table 1. Flower buds from 16 plants were collected from population A (located in fragment A). Flower buds from 20 plants each were collected from populations B, C, and D (located in fragments B, C, and D, respectively).

\section{Microsporogenesis analysis}

Meiosis analyses were performed in meiocytes isolated from flower buds that were collected from plants of each population. To collect flower buds from plants of the same generation, plants that had a diameter at breast height of 0.15 to $0.20 \mathrm{~m}$ were selected from each population. After collection, the flower buds were fixed for $24 \mathrm{~h}$ in Carnoy's solution (3:1, ethanol:glacial acetic acid). Once set, the buds were transferred to $70 \%$ alcohol and refrigerated until slides could be prepared. To prepare the slides, the anthers of each flower bud were isolated, squashed, stained with $0.5 \%$ propionic carmine, and inspected using a white-light microscope. A minimum of 5 plants were examined from each population, and a minimum of 
50 cells in each phase of meiosis from at least 4 flower buds were examined from each plant; thus, a total of about 9000 cells were examined. All abnormalities were considered, and the most representative were photographed with an image-capture system coupled to the microscope. The number of chromosomes in the samples was determined by counting the number of bivalent chromosomes at the diakinesis stage.

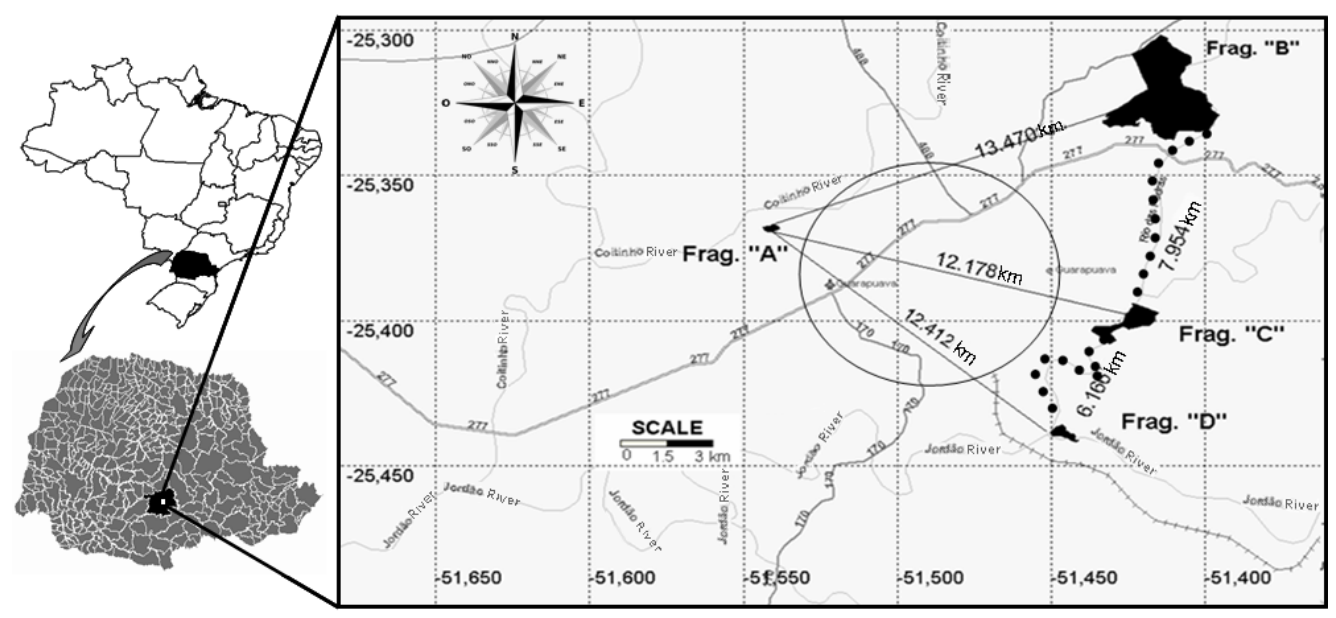

Figure 1. Map of the Atlantic Forest fragments where the populations of Eugenia uniflora used in this study were collected, showing the distance between the fragments (in kilometers). The dotted curved line indicates the forest corridor connecting fragments B, C, and D. The circle indicates the urban area of Guarapuava.

Table 1. Summary of the characteristics of Eugenia uniflora populations from the Atlantic Forest used in this study and number of plants sampled in each population.

\begin{tabular}{lccccc}
\hline Fragment & Size (acres) & Geographic coordinates & No. of plants sampled & Age of secondary forest (years) & Forest corridor \\
\hline A & 8 & $25^{\circ} 22^{\prime} 05,45^{\prime \prime} \mathrm{S} 51^{\circ} 32^{\prime} 27,16^{\prime \prime} \mathrm{O}$ & 16 & 29 & No \\
B & 120 & $25^{\circ} 19^{2} 24,34^{\prime \prime} \mathrm{S} 51^{\circ} 24^{\prime} 51,42^{\prime \prime} \mathrm{O}$ & 20 & 41 & Yes \\
C & 60 & $25^{\circ} 24^{\prime} 01,177^{\prime \prime} \mathrm{S} 51^{\circ} 25^{\prime} 45,74^{\prime \prime} \mathrm{O}$ & 20 & 20 & Yes \\
D & 35 & $25^{\circ} 26^{\prime} 03,04^{\prime \prime} \mathrm{S} 51^{\circ} 26^{\prime} 50,78^{\prime \prime} \mathrm{O}$ & 20 & 23 & Yes \\
\hline
\end{tabular}

\section{Analysis of pollen viability}

To evaluate pollen viability, 16 plants were analyzed from population A and 20 plants each from populations B, C, and D. Four flower buds were taken from each plant, and each flower bud contained 500 pollen grains (a total of approximately 152,000 pollen grains). The flower buds used for pollen viability were fully expanded, but in the pre-anthesis stage. To prepare the slides, the anthers of each flower bud were isolated, squashed, and stained with $0.5 \%$ propionic carmine. Unstained pollen grains and those that appeared to have degenerating genetic material were considered unviable.

\section{Statistical analysis}

The meiotic index (MI) was calculated, according to the method described by Love 
(1949), as follows: $\mathrm{MI}=$ (number of normal tetrads / total number of tetrads) $\mathrm{x} 100$, and samples with an MI of more than $85 \%$ were considered meiotically stable. Statistical analysis of the MI values among the populations studied was performed using the chi-square test $\left(\chi^{2}\right)$.

Statistical analysis of pollen grain viability from the 4 fragments was performed using a randomized design, in which the number of flower buds analyzed in each population corresponded to the number of repetitions. Mean values were compared using the Tukey test at $1 \%$. Statistical analysis was performed with the GENES software (Cruz, 2006). Pearson's correlation was used to determine the correlation between the percentage of viable pollen grains and viable tetrads from each population.

\section{RESULTS}

With the exception of diakinesis, which was analyzed to determine the number of chromosomes, the sub-phases of prophase I were not evaluated because of the small size of the meiotic cells. When the chromosomes in diakinesis were counted, the presence of 11 bivalents ( 22 chromosomes) was found in all samples. These data confirmed that all the specimens analyzed were E. uniflora, refuting the presence of E. pitanga, which is morphologically very similar to E. uniflora but has 44 chromosomes.

Analysis of meiosis revealed abnormalities in all the populations studied; however, in population A, which was isolated by agricultural areas, the abnormalities were more frequent (Table 2). Metaphase I of population A showed 13\% abnormalities, while that in the other populations showed 3-4\% abnormal cells (Table 2). The abnormalities observed in metaphase I were precocious migration of univalents to the poles (Figure 2a). Anaphase I in population A showed $21 \%$ abnormal cells, while that in the other populations showed 4 to $5 \%$ abnormal cells (Table 2). Late chiasmata terminalization (Figure 2b) and laggard chromosomes (Figure 2c) were the more frequent abnormalities observed in anaphase I. The laggard chromosomes observed in anaphase I gave rise to micronuclei in telophase I and prophase II. Abnormalities were also observed in meiosis II and, again, more frequently in population A (Table 2). Precocious chromatid migration to the cell poles was observed in metaphase II (Figure 2d), and laggard chromosomes were observed in anaphase II (Figure 2e). These abnormalities gave rise to the formation of micronuclei in telophase II (Figure $2 \mathrm{f}$ and $\mathrm{g}$ ) and a pentad containing 4 normal-size and 1 small microcyte (Figure $2 \mathrm{~h}$ ). Other abnormalities observed were an asynchronous phase and convergent spindles. Convergent spindles lead to the formation of trinucleated anaphase II and telophase II with restitution nuclei (2n) (Figure 3a and b) and consequent formation of triads (Figure $3 \mathrm{c}$ ). These triads formed unreduced pollen grains (Figure $3 \mathrm{~d}$ ). The presence of convergent spindles, triads, and unreduced pollen grains was observed only in population A. In addition to these abnormalities, the presence of tetrads with 2 unreduced microcytes and 2 small microcytes was observed (Figure $3 i$ ).

Population A had the lowest MI (Table 2), and the $\chi^{2}$ test showed a significant difference in the MI value when compared to that of the other populations $(\mathrm{P}=0.030)$.

The analysis of pollen viability showed the presence of sterile and reduced-size pollen grains in all the populations tested (Figure $3 \mathrm{~d}$, e, and f). Unreduced pollen grains were also observed in population A (Figure 3d). The percentage of abnormalities in population A was higher than that in the other populations (Table 2). Analysis of variance confirmed that there were significant differences among the populations with regard to the percentage of viable 
pollen grains (Table 3). Populations $\mathrm{C}$ and $\mathrm{D}$ had the highest average percentage of viable pollen grains, with no differences between them; however, they differed significantly from populations A and B (results of the Tukey test), with population A showing the smallest average percentage of viable pollen grains (Table 4).

Table 2. Percentage of normal meiocytes and meiotic index (MI) in 4 populations of Eugenia uniflora collected in fragments of the Atlantic Forest in the south-central region of Paraná, Brazil.

\begin{tabular}{|c|c|c|c|c|c|c|c|c|c|}
\hline \multirow[t]{2}{*}{ Fragment } & \multicolumn{3}{|c|}{ Meiosis I } & \multicolumn{4}{|c|}{ Meiosis II } & \multirow[t]{2}{*}{ Tetrad } & \multirow[t]{2}{*}{ MI } \\
\hline & Met I & Ana I & Tel I & Pro II & Met II & Ana II & Tel II & & \\
\hline A & $87 \%$ & $79 \%$ & $84 \%$ & $82 \%$ & $79 \%$ & $71 \%$ & $87 \%$ & $73 \%$ & $70.8 \%$ \\
\hline B & $96 \%$ & $95 \%$ & $96 \%$ & $98 \%$ & $96 \%$ & $94 \%$ & $96 \%$ & $88 \%$ & $95.2 \%$ \\
\hline C & $97 \%$ & $96 \%$ & $98 \%$ & $100 \%$ & $97 \%$ & $96 \%$ & $96 \%$ & $93 \%$ & $97.2 \%$ \\
\hline D & $96 \%$ & $96 \%$ & $100 \%$ & $99 \%$ & $96 \%$ & $96 \%$ & $99 \%$ & $100 \%$ & $100 \%$ \\
\hline
\end{tabular}

Met $=$ metaphase; Ana $=$ anaphase $;$ Tel = telophase; Pro $=$ prophase.
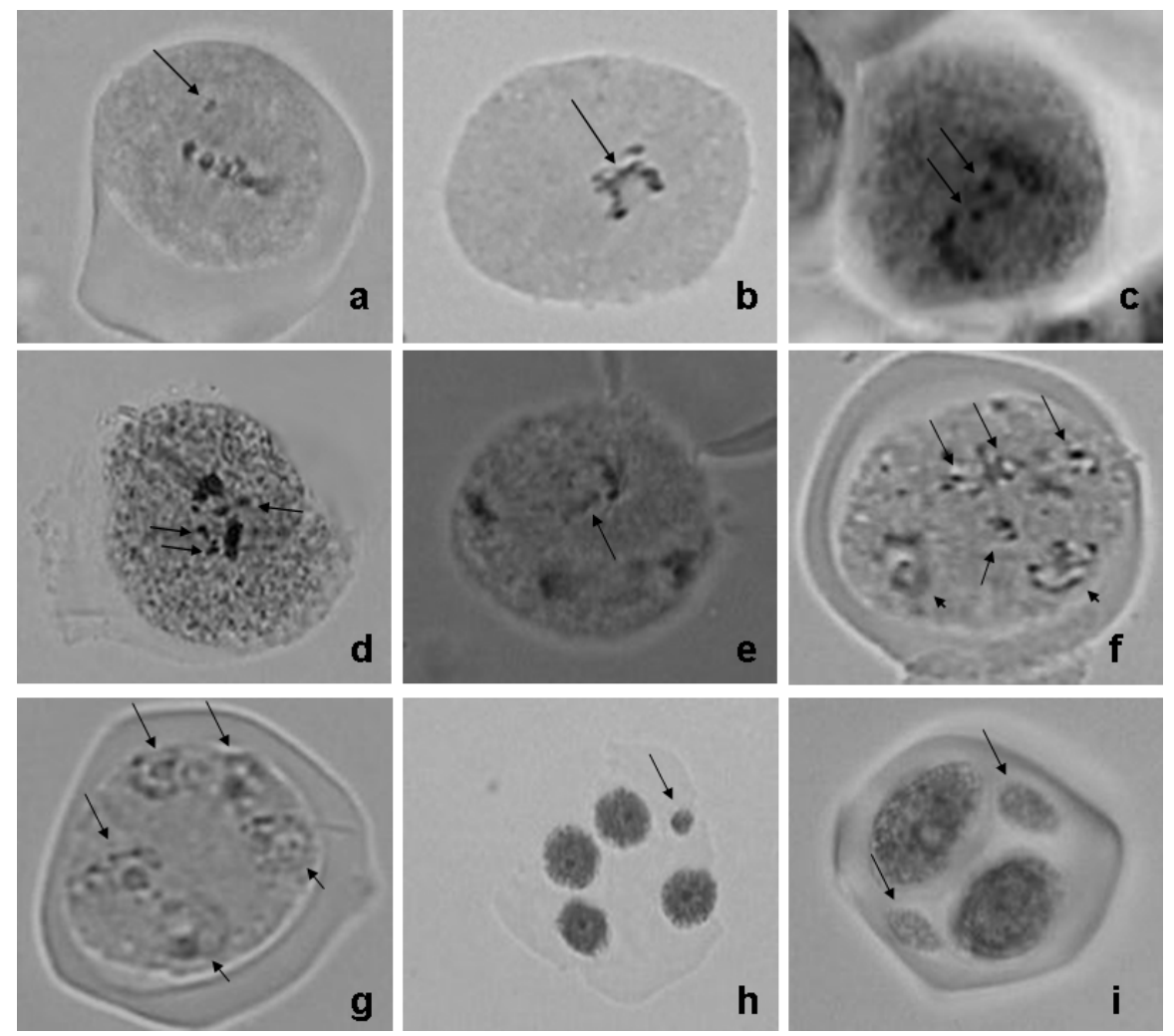

Figure 2. Aspects of meiosis in Eugenia uniflora. a. Metaphase I with precocious migration of univalents to the poles (arrow); b. anaphase I with chiasmata not terminalized (arrow); c. anaphase I with laggard chromosomes (arrows); d. metaphase II with precocious chromatid migration to the cell poles (arrows); e. anaphase II with lagging chromosomes (arrow); f. telophase II with 2 apparently normal nuclei (short arrows) and 4 micronuclei (long arrows); g. telophase II with 5 microcytes (each arrow indicates a nucleus); $\mathbf{h}$. tetrad with a small pollen grain (arrow); i. tetrad with 2 unreduced microcytes ( $2 \mathrm{n})$ and 2 small microcytes (arrow). Figure 2a-g, and 2i: magnification $=1000 \mathrm{X}$; figure $2 \mathrm{~h}$ : magnification $=400 \mathrm{X}$. 

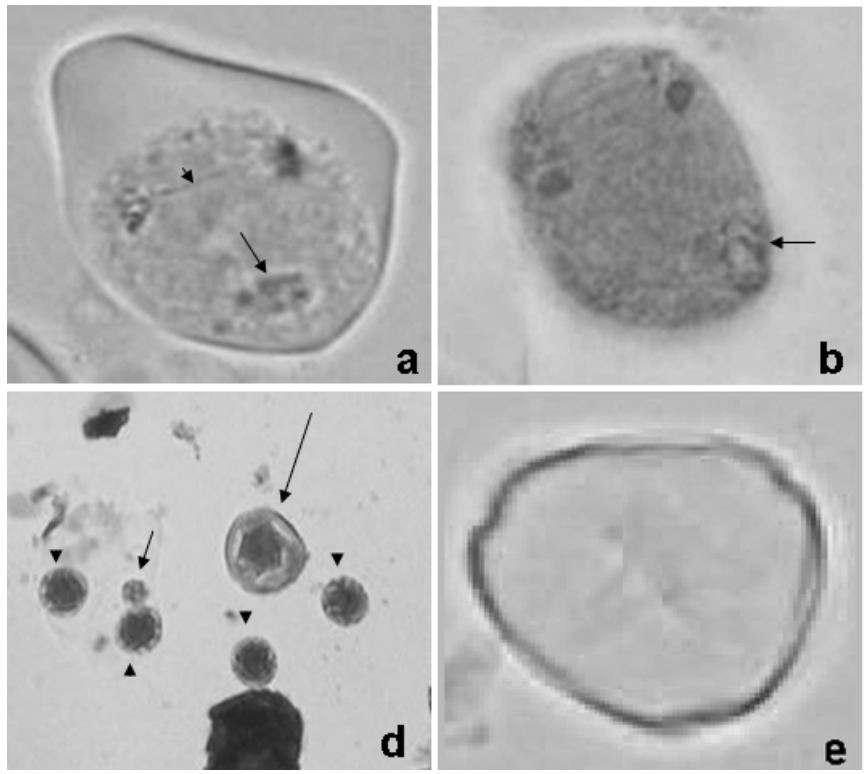
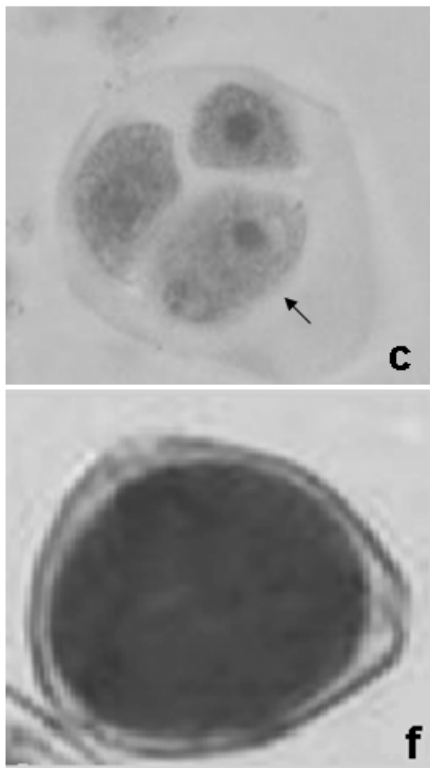

Figure 3. Aspects of the final stages of meiosis and pollen grains of Eugenia uniflora. a. anaphase II with one not reduced nuclei (long arrow) and a bridge between nuclei (short arrow); b. telophase II trinucleated with restitution nuclei (arrow); c. triad with 2 normal microsporocytes and 1 not reduced (arrow); d. normal pollen grains (arrowheads), not reduced (large arrow), and small (small arrow); e. sterile pollen grain; f. fertile pollen grain. Figures 3a-f: magnification $=1000 \mathrm{X}$, figure $3 \mathrm{~d}$ : magnification $=400 \mathrm{X}$.

Table 3. Analysis of variance of the percentage of normal pollen grains of the flower buds sampled in 4 populations of Eugenia uniflora collected from fragments in the Atlantic Forest in the south-central region of Paraná, Brazil.

\begin{tabular}{lcccc}
\hline Source & d.f. & Sum of square & Mean square & F-ratio \\
\hline Population & 3 & 9734.3124 & 3244.7708 & 153.93 \\
Residual & 300 & 6323.8064 & 21.0793 & \\
Total & 303 & 16058.1188 & & \\
Overall average & 93.22 & & & \\
CV $(\%)$ & 4.92 & & & \\
\hline
\end{tabular}

d.f. $=$ degrees of freedom; $\mathrm{CV}=$ coefficient of variation.

Table 4. Pollen viability in 4 populations of Eugenia uniflora collected in fragments of the Atlantic Forest in the south-central region of Paraná, Brazil.

\begin{tabular}{lcccc}
\hline Fragment & $\begin{array}{c}\text { No. of plants } \\
\text { sampled }\end{array}$ & $\begin{array}{c}\text { No. of flower } \\
\text { buds sampled }\end{array}$ & $\begin{array}{c}\text { No. of pollen } \\
\text { grains sampled }\end{array}$ & $\begin{array}{c}\text { Average percentage of } \\
\text { viable pollen grains* }\end{array}$ \\
\hline A & 16 & 64 & 32,000 & $82.62 \%^{\mathrm{a}}$ \\
B & 20 & 80 & 40,000 & $93.06 \%^{\mathrm{b}}$ \\
C & 20 & 80 & 40,000 & $96.77 \%^{\mathrm{c}}$ \\
D & 20 & 80 & 40,000 & $97.59 \%^{\mathrm{c}}$ \\
\hline
\end{tabular}

*Means followed by the same superscript letters do not differ by the Tukey test at $1 \%$.

The values of the standard deviation calculated for the percentage of viable pollen grains of plants sampled from each population were as follows: A (9.10), B (2.98), C (1.78), and D (1.34). These data show that plants from isolated populations have the highest levels of variation. 


\section{DISCUSSION}

The isolation of plants resulting from forest fragmentation can decrease populationsize and enable crosses between plants that have a high degree of kinship. These crosses in allogamous species can cause homozygosity in alleles that control meiosis, leading to gene depression due to endogamy. Genetic depression can compromise plant fertility. According to Pagliarini (2000), the fertility of plants is the product of meiotic behavior, and the formation of functional gametes is controlled by genes that ensure a normal meiotic process. These alleles in a homozygous condition and/or when they have mutated can affect the fertility of the species (Baker et al., 1976; Golubovskaya, 1979; Pagliarini, 2000).

The evaluation of microsporogenesis in E. uniflora populations studied here is summarized in Table 2. Analysis of these data showed that in plants of populations B, C, and D, an average of $94-100 \%$ normal cells were in meiosis I and II. This result showed a tendency toward correction in prophase II and telophase II of the abnormalities observed in the phases of association and disjunction of meiosis I and II (metaphase and anaphase). Population A, which was isolated by agricultural areas, showed an average of 71-87\% normal cells in meiosis I and II, with the smallest average observed during anaphase II. The variation between the phases of association and disjunction was small and did not show a correction process.

Although population A showed a high rate of abnormalities during meiosis I, it was during meiosis II that the abnormalities increased in number (Table 2); this directly affected the production of abnormal tetrads. Pearson's correlation coefficient between the percentage of abnormal pollen grains and the percentage of abnormal tetrads was calculated using the average values of 5 plants from population $\mathrm{A}(\mathrm{P}=0.87)$, and it indicated a strong correlation between these characteristics. This shows that pollen sterility observed in the plants from fragment $\mathrm{A}$ is a consequence of abnormalities observed during meiosis. Fragment $\mathrm{D}$ was the most stable during the stages of microsporogenesis and did not present any abnormal tetrads in the material analyzed. Although this fragment is the smallest (Table 1), its geographical situation leads to inferences about the intensity of gene flow because its location not only allows flow from the studied fragments, located in the Pedras River basin, but also from fragments not studied and located in the Bananas River basin. This finding shows the importance of forest corridors in maintaining a stable population. Aizen (2007) discussed the simplicity of research related to the effects of fragmentation and argued that presumptions usually do not offer a real explanation of the mechanisms underlying the observed reproductive inability. The author emphasized the need to observe the factors inherent in the plant, fragment, and pollinators. Aizen (2007) observed that there are limited studies on the mechanisms that lead to changes in reproduction. In our study, we sought to fill one of these gaps and showed that populations of E. uniflora in isolated fragments had high meiotic abnormalities, which, in turn, resulted in compromised viability of pollen grains. These data lead us to propose that this species suffers from genetic inbreeding depression. Bittencourt and Sebbenn (2009) conducted a study using molecular markers to compare populations of Araucaria angustifolia in isolated fragments and large conservation areas. They observed that the isolated populations had fewer alleles than the populations from large conservation areas; this leads us to conclude that the isolated populations of $A$. angustifolia suffered from genetic depression. Our group is currently using molecular techniques to analyze the populations of E. uniflora at the DNA level to confirm the data observed in microsporogenesis studies. 
Plants from fragments B, C, and D had a high rate of pollen grain viability (more than 93\%) (Table 3), while the viability of the pollen grains of plants from fragment A was, on average, $82.62 \%$, which is much lower than that of the other fragments (Table 3). Aguilar and Galetto (2004) observed a reduction in pollen viability in Cestrum parqui, which, according to the authors, is highly sensitive to fragmentation. They concluded that the effects of inbreeding, enhanced by fragmentation, are possible causes for the observed low reproductive vigor. Cunningham (2000), who studied plants of Acacia brachybotrya from fragments of vegetation in Australia, observed a lower number of pollen grains in the anthers of samples from the fragmented populations than those of samples from populations of large reserves. They also observed a decrease in fruitfulness of the populations in fragmented areas. This study illustrates that, compared to populations in connected areas, population isolation caused by habitat fragmentation can produce a decline in pollination and fruit formation. The same result was observed in our study, showing that E. uniflora is also a species sensitive to fragmentation.

The MI values of the populations from connected areas ranged from 95.2 to $100 \%$ and the value of the population from the isolated area was $70.8 \%$ (Table 2). According to Love (1949), an MI value of less than $85 \%$ demonstrates non-viability; plants whose MIs were greater than $85 \%$ were considered to be normal with respect to meiotic behavior, and therefore, genetically stable. Loguercio and Battistin (2004) who studied populations of Syzygium jambolanum, a member of the Myrtaceae family, as well as E. uniflora (all collected from preserved areas) observed an MI value of more than $90 \%$ and few irregularities in microsporogenesis, indicating that their populations are meiotically stable. In our study, populations of E. uniflora from conserved areas were shown to be meiotically stable as well. These data assist in confirming that the plants collected from population A of E. uniflora (the isolated fragment) had unstable microsporogenesis owing to the negative effect of isolation.

The high pollen viability observed in populations B, C, and D that are connected by corridors may be the result of the greater stability of the genes that control meiosis. This stability may be associated with factors such as gene flow, which is a gene-stabilizing factor in populations, in concert with other factors such as genetic drift, mutation, and recombination, which reflect the genetic variability of a population (Bierregaard et al., 1992; Young and Boyle, 2000; Santos and Kinoshita, 2003). In contrast, plants in fragment A may suffer the effects of inbreeding owing to fragmentation and limitation of gene flow.

The observation of triads in the samples from population A (Figure 3) has evolutionary significance because the production of $2 \mathrm{n}$ gametes can lead to polyploidization processes (Auler et al., 2006). Costa and Forni-Martins (2006), in his study on cytotaxonomy of the family Myrtaceae, identified a possible polyploid of E. uniflora as E. pitanga. This species has double the chromosome number of $E$. uniflora. Although he did not identify processes that can lead to this polyploidization, it is easy to infer that the non-reduction of both gametes (male and female) of $E$. uniflora following fertilization may have been the mechanism by which $E$. pitanga originated. Further studies are necessary to determine whether this theory is accurate; however, it is possible that E. pitanga emerged as a result of polyploidization of E. uniflora.

\section{CONCLUSION}

Our results show that the isolation of populations, caused by forest fragmentation, has direct effects on microsporogenesis in populations of E. uniflora, leading to increased 
frequency of meiotic abnormalities, and, consequently, lower pollen viability. These isolated populations have decreased reproductive capacity and may, in the long run, compromise the future of the species.

\section{REFERENCES}

Aguilar R and Galetto L (2004). Effects of forest fragmentation on male and female reproductive success in Cestrum parqui (Solanaceae). Oecologia 138: 513-520.

Aizen MA (2007). Enfoques en el estudio de la reproduccíon sexual de las plantas en ambientes alterados: limitaciones y perspectivas. Ecol. Austral 17: 7-19.

Aizen MA and Feinsinger P (1994). Forest fragmentation, pollination, and plant reproduction in a Chaco dry forest, Argentina. Ecology 75: 330-351.

Armbrecht I and Perfecto I (2003). Litter-Twig dwelling ant species richness and predation potential within a forest fragment and neighboring coffee plantations of contrasting habitat quality in Mexico. Agric. Ecosys. Environ. 97: 107-115.

Auler NMF, Battistin A and Reis MS (2006). Number of chromosomes, microsporogenesis and pollen viability in populations of carqueja [Baccharis trimera (Less.) DC.] from Rio Grande do Sul and Santa Catarina. Rev. Bras. Plantas Med. 8: 55-63.

Baker BS, Carpenter AT, Esposito MS, Esposito RE, et al. (1976). The genetic control of meiosis. Annu. Rev. Genet. 10: 53-134.

Barret SCH, Price SD and Shore JS (1983). Male fertility and anisoplethic population structure in tristylous Pontederia cordata (Pontederiaceae). Evolution 37: 745-759.

Becker P, Moure JS and Peralta FJA (1991). More about euglossine bees in Amazonian forest fragments. Biotropica 23: 586-591.

Bierregaard RO Jr, Lovejoy TE, Kapos V, Santos AA, et al. (1992). The biological dynamics of tropical rainforest fragments. BioSciences 42: 859-866.

Bittencourt JVM and Sebbenn AM (2009). Genetic effects of forest fragmentation in high-density Araucaria angustifolia populations in Southern Brazil. Tree Genet. Genomes 5: 573-582.

Costa IR and Forni-Martins ER (2006). Chromosome studies in species of Eugenia, Myrciaria and Plinia (Myrtaceae) from south-eastern Brazil. Aust. J. Bot. 54: 409-415.

Cruz CD (2006). Programa GENES - Versão Windows. Aplicativo Computacional em Genética e Estatística. UFV, Viçosa.

Cunningham SA (2000). Depressed pollination in habitat fragments causes low fruit set. Proc. Biol. Sci. 267: 1149-1152.

Didham RK (1998). Altered leaf-litter decomposition rates in tropical forest fragments. Oecologia 116: 397-406.

Ellstrand NC and Elam DR (1993). Population genetic consequences of small population size: implications for plant conservation. Annu. Rev. Ecol. Syst. 24: 217-242.

Estopa RA, Ramalho MAP, Rezende GDSP, Abad JIM, et al. (2007). Performance of inbred and outbred Eucalyptus spp. Cerne 13: 264-270.

Ferreira MAJF, Queiróz MA, Vencovsky R, Braz LT, et al. (2002). Sexual expression and mating system of watermelon: implications for breeding programs. $C B A B$ 75: 171-177.

Golubovskaya IN (1979). Genetic control of meiosis. Int. Rev. Cytol. 58: 247-290.

Green DG (1994). Connectivity and complexity in landscapes and ecosystems. Pacific Cons. Biol. 1: 194-200.

Hedrick PW and Miller PS (1992). Conservation genetics: techniques and fundamentals. J. Appl. Ecol. 2: 30-46.

Kapos V (1989). Effects of isolation on the water status of forest patches in the Brazilian Amazon. J. Trop. Ecol. 5: 173-185.

Laurance WF, Lovejoy TE, Vasconcelos HL, Bruna EM, et al. (2002). Ecosystem decay of Amazonian forest fragments: a 22-year investigation. Conserv. Biol. 16: 605-618.

Loguercio AP and Battistin A (2004). Microsporogenesis of nine access of Syzygium cumini (L.) Skeels) Myrtaceae from Rio Grande do Sul - Brazil. Rev. FZVA 11: 95-106.

Love RM (1949). La citología como ayuda práctica al mejoramiento de los cereales. Rev. Arg. Agron. 16: 1-13.

Noss RF (1987). Corridors in real landscapes: a reply to Simberloff and Cox. Conserv. Biol. 2: 159-164.

Pagliarini MS (2000). Meiotic behavior of economically important plant species: the relationship between fertility and male sterility. Genet. Mol. Biol. 23: 997-1002.

Pagliarini MS, Defani MA, Walter FM and Pereira JE (2002). Recurrence of multiple abnormalities in maize genotypes from the same origin and their influence on productivity. $C B A B$ 2: 355-360.

Pelacani MGN, Jesus ARG, Spina SM and Figueiredo RA (2000). Biologia floral da pitangueira (Eugenia uniflora L., 
Myrtaceae). Argumento 4: 17-20.

Piroli EL and Nascimento ART (2008). Analysis and phytosociological structure of a Mixed Ombrophylous Forest fragment in the city of Sertão, RS. Ambiência 4: 91-103.

Ricci GC, Silva N, Pagliarini MS and Scapim CA (2007). Microsporogenesis in inbred line of popcorn (Zea mays L.). Genet. Mol. Res. 6: 1013-1018.

Rodríguez-Cabala MA, Aizen MA and Novaro AJ (2007). Habitat fragmentation disrupts a plant-disperser mutualism in the temperate forest of South America. Conserv. Biol. 139: 195-202.

Santos K and Kinoshita LS (2003). Floristic composition of the woody flora of the Ribeirão Cachoeira forest, Campinas, São Paulo State. Acta Bot. Bras. 17: 325-341.

Turner IM (1996). Species loss in fragments of tropical rain forest: a review of the evidence. J. Appl. Ecol. 33: 200-209.

Wielgoss A, Tscharntke T, Buchori D, Fiala B, et al. (2010). Temperature and a dominant dolichoderine ant species affect ant diversity in Indonesian cacao plantations. Agric. Ecosys. Environ. 135: 253-259.

Young A and Boyle TJ (2000). Forest Fragmentation. Forest Conservation Genetics: Principles and Practice. Csiro Publishing, Collingwood. 